\title{
The effect of dietary sodium intake on biochemical markers of bone metabolism in young women
}

\author{
Fiona Ginty, Albert Flynn and Kevin D. Cashman* \\ Department of Nutrition, University College, Cork, Ireland
}

(Received 13 October 1997-Accepted 27 October 1997)

\begin{abstract}
To investigate the effect of a low $(80 \mathrm{mmol} / \mathrm{d})$ or high $(180 \mathrm{mmol} / \mathrm{d}) \mathrm{Na}$ intake for $14 \mathrm{~d}$ on biochemical markers of bone turnover in Na-sensitive and Na-non-sensitive healthy young women, twenty-nine subjects were screened for responsiveness of urinary $\mathrm{Ca}$ excretion to increasing dietary $\mathrm{Na}$ intake $(40,80,120$ and $200 \mathrm{mmol} / \mathrm{d}$ for $7 \mathrm{~d})$. In a crossover study, the eight Na-sensitive and eight of the twenty-one Na-non-sensitive subjects were randomly assigned to diets containing either 80 or $180 \mathrm{mmol} \mathrm{Na} / \mathrm{d}$ for $14 \mathrm{~d}$ followed by crossover to the alternative diet for a further $14 \mathrm{~d}$. Dietary $\mathrm{Ca}$ was restricted to $12.5 \mathrm{mmol} / \mathrm{d}$ throughout. During each dietary period, fasting morning first void urine samples (last $3 \mathrm{~d}$ ) and fasting blood serum samples (morning of twelfth day) were collected. Increasing Na intake from 80 to $180 \mathrm{mmol} / \mathrm{d}$ increased urinary $\mathrm{Na}$ about twofold in both the $\mathrm{Na}$-sensitive and $\mathrm{Na}$-non-sensitive groups and increased urinary $\mathrm{Ca}$ excretion (by $73 \%$ ) in the Na-sensitive group only. Biochemical markers of bone resorption (urinary pyridinoline and deoxypyridinoline) and bone formation (serum osteocalcin and bone-specific alkaline phosphatase; $E C$ 3.1.3.1) were unaffected by increasing dietary $\mathrm{Na}$ in either group. It is concluded that the $\mathrm{Na}$-induced calciuria observed in the Nasensitive healthy young women did not result in increased bone resorption or turnover and, despite restricted $\mathrm{Ca}$ intake, adaptation of dietary $\mathrm{Ca}$ absorption may have compensated for the increased urinary $\mathrm{Ca}$ loss.
\end{abstract}

Sodium: Bone: Biochemical markers: Premenopausal women

There is evidence that high dietary Na intake may have adverse effects on bone metabolism and may be a risk factor for osteoporosis. Increasing $\mathrm{Na}$ intake within the range of usual dietary intakes is associated with increased urinary Ca loss (Aub et al. 1937; Hills et al. 1959; King et al. 1964; Kleeman et al. 1964; Shortt et al. 1988; Shortt \& Flynn, 1990). It has been estimated that a $100 \mathrm{mmol}$ increment in daily $\mathrm{Na}$ intake is associated with an average loss of urinary Ca of approximately $1 \mathrm{mmol}$ in free-living normocalciuric healthy populations (Nordin et al. 1993). There is also a large inter-individual variation in $\mathrm{Na}-$ induced calciuria ranging from a strong response in some individuals to no detectable response in others (Shortt et al. 1988). It is not known to what extent Na-induced calciuria is compensated for by increased absorption of dietary $\mathrm{Ca}$ or to what extent this $\mathrm{Ca}$ is derived from resorption of bone (Shortt \& Flynn, 1990).
There is evidence that very high $\mathrm{Na}$ intakes reduce bone mass and bone $\mathrm{Ca}$ content in rats (see review by Shortt \& Flynn, 1990). However, the limited number of studies which have investigated the association of dietary $\mathrm{Na}$ with bone mineral density in human subjects have produced conflicting results (Nordin \& Polley, 1987; Greendale et al. 1994; Devine et al. 1995; Matkovic et al. 1995).

There is also evidence that urinary hydroxyproline, a marker of bone resorption, is increased with increasing $\mathrm{Na}$ intake (Goulding, 1981; Goulding \& Lim, 1983; Nordin \& Polley, 1987; McParland et al. 1989; Need et al. 1991; Itoh \& Suyama, 1996). However, urinary hydroxyproline has been shown to lack sensitivity and specificity as an indicator of bone resorption and urinary pyridinium crosslinks of collagen are considered to be more reliable biochemical markers of bone resorption (Delmas, 1992; Leitz et al. 1997).

\footnotetext{
Abbreviations: $\mathrm{Cr}$, creatinine; Dpyr, deoxypyridinoline; PTH, parathyroid hormone; Pyr, pyridinoline. *Corresponding author: Dr Kevin Cashman, fax + 35321270244 , email K.Cashman@UCC.ie
} 
Two recent studies have investigated the effects of dietary $\mathrm{Na}$ on urinary pyridinium crosslinks of collagen. Lietz et al. (1997) showed that there was no significant difference in deoxypyridinoline (Dpyr) excretion in postmenopausal women consuming a fixed diet containing either high $(170 \mathrm{mmol} / \mathrm{d})$ or low $(60 \mathrm{mmol} / \mathrm{d})$ levels of $\mathrm{Na}$ for $8 \mathrm{~d}$ while on a fixed Ca intake $(20 \mathrm{mmol} / \mathrm{d})$. Evans $e t$ al. (1997) reported that urinary excretion of Dpyr was higher following $7 \mathrm{~d}$ on a high $-\mathrm{Na}$ diet $(300 \mathrm{mmol} / \mathrm{d})$ than a low$\mathrm{Na}$ diet $(50 \mathrm{mmol} / \mathrm{d})$ for postmenopausal but not premenopausal women. However, neither of these studies considered the large inter-individual variation in $\mathrm{Na}$ induced calciuria which has been reported to occur.

Thus, the objectives of the present study were to investigate the effect of dietary $\mathrm{Na}$ on biomarkers of bone metabolism in healthy buman subjects and to examine the influence of the responsiveness of urinary $\mathrm{Ca}$ to changing dietary $\mathrm{Na}$ intake on this.

\section{Methods}

\section{Subjects}

Twenty-nine young healthy adult females (mean age 24.5 (range 22-28) years) were recruited from among a group of postgraduates at University College, Cork. The mean height, weight and BMI of the subjects are provided in Table 1. The subjects were healthy without any history of bone or articular disease, and with no intake of medicine that could affect bone or cartilage metabolism. Additional exclusion criteria included chronic illness or established or familial history of hypertension. Subjects were requested to avoid vigorous exercise and excessive alcohol intake for the duration of the study.

\section{Ethical considerations}

Before participation in this study, all subjects signed an informed consent document approved by the Clinical Research Ethics Committee of the Cork Teaching Hospitals.

\section{Design}

The study consisted of a randomized crossover trial of the effect of 'low' $(80 \mathrm{mmol} / \mathrm{d})$ or 'high' $(180 \mathrm{mmol} / \mathrm{d}) \mathrm{Na}$ intake for $14 \mathrm{~d}$ on biochemical markers of bone turnover in

Table 1. Characteristics of the group of healthy young adult female volunteers $(n 29)$ who were screened for responsiveness of urinary calcium to dietary sodium

(Mean values with their standard errors, and range)

\begin{tabular}{lccc}
\hline & Mean & \multicolumn{1}{c}{ SEM } & Range \\
\hline Age (years) & 24.5 & 0.5 & $22-28$ \\
Height $(\mathrm{m})$ & 1.65 & 0.06 & $1.52-1.76$ \\
Weight $(\mathrm{kg})$ & 58.5 & 1.1 & $50-70$ \\
BMI $\left(\mathrm{kg} / \mathrm{m}^{2}\right)$ & 21.5 & 0.3 & $18.2-25.9$ \\
\hline
\end{tabular}

subjects selected on the basis of the responsiveness or nonresponsiveness of urinary $\mathrm{Ca}$ to dietary $\mathrm{Na}$ (Fig. 1).

To screen subjects for responsiveness of urinary $\mathrm{Ca}$ to dietary $\mathrm{Na}$, twenty-nine subjects consumed, for $7 \mathrm{~d}$ each, four diets which were formulated to contain varying levels of $\mathrm{Na}$ in the following order: $40,80,120$ and $200 \mathrm{mmol} / \mathrm{d}$ while maintaining dietary $\mathrm{Ca}$ intake at $12.5 \mathrm{mmol}$ $(500 \mathrm{mg}) / \mathrm{d}$ (Shortt et al. 1988). Subjects were instructed to consume each diet for 7 consecutive days and a period of $5 \mathrm{~d}$ elapsed between each dietary regimen. Subjects were instructed to collect fasting first morning void urine samples and to complete a $24 \mathrm{~h}$ diet recall of food intake for each of the last $3 \mathrm{~d}$ of the different dietary regimens. Urine samples were analysed for $\mathrm{Na}, \mathrm{Ca}$ and creatinine $(\mathrm{Cr})$ and the urinary $\mathrm{Ca}$ concentration, $\mathrm{Cr}$-corrected $(\mathrm{Ca} / \mathrm{Cr})$, was plotted against urinary $\mathrm{Na}$ concentration, also $\mathrm{Cr}$ corrected $(\mathrm{Na} / \mathrm{Cr})$, for each subject. The relationship between urinary $\mathrm{Ca} / \mathrm{Cr}$ and urinary $\mathrm{Na} / \mathrm{Cr}$ was analysed by single linear regression analysis and Pearson's correlation coefficients for each subject. Subjects were categorized as ' $\mathrm{Na}$ sensitive' or 'Na-non-sensitive' on the basis of the presence or absence of statistical significance for this relationship (Fig. 2). On this basis eight Na-sensitive and eight Na-non-sensitive subjects were selected.

Following the screening period, selected subjects continued to consume the Ca-controlled diet $(12.5 \mathrm{mmol} / \mathrm{d})$ with no control of $\mathrm{Na}$ intake for 1 week, after which time they took part in the randomized crossover design $\mathrm{Na}$ intervention trial.

The $\mathrm{Na}$ intervention trial was designed in two periods, each of $14 \mathrm{~d}$, in which the $\mathrm{Na}$ intakes were manipulated to be 80 or $180 \mathrm{mmol} \mathrm{Na} / \mathrm{d}$ (Shortt et al. 1988) while $\mathrm{Ca}$ intake was maintained at $12.5 \mathrm{mmol} / \mathrm{d}$. Na-sensitive and Na-non-sensitive subjects were randomly assigned to lowor high-Na diet regimens for $14 \mathrm{~d}$ followed by crossover to the alternative dietary regimen for a further $14 \mathrm{~d}$ (Fig. 1). Subjects were instructed to collect fasting first void urine samples between 07.00 and 09.00 hours for the last $3 \mathrm{~d}$ of each treatment period to allow a washout period as previously suggested (Shortt et al. 1988). The $24 \mathrm{~h}$ diet recalls for each individual were also obtained on each of these days. In addition, after an overnight fast, a blood sample $(10 \mathrm{ml})$ was taken at 09.00 hours on the morning of the twelfth day of each dietary period.

\section{Dietary analysis}

Nutrient intakes were estimated from $24 \mathrm{~h}$ diet recall data for food consumption using the McCance and Widdowson's The Composition of Foods (Paul \& Southgate, 1978) database (Microdiet, Salford, Greater Manchester, UK).

\section{Collection and preparation of samples}

Subjects were supplied with suitable collection containers for urine samples and asked to collect fasting first void morning urine samples between 07.00 and 09.00 hours each day for the last three consecutive days of each dietary 
Group A (four Na-sensitive and four Na-non-sensitive subjects)

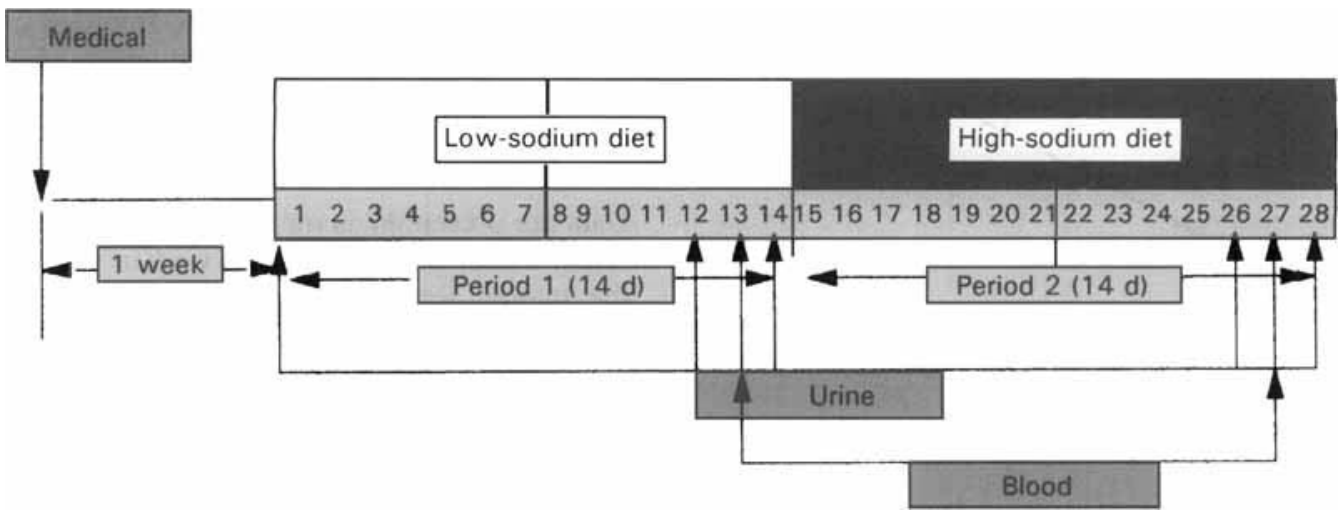

Group B (four Na-sensitive and four Na-non-sensitive subjects)

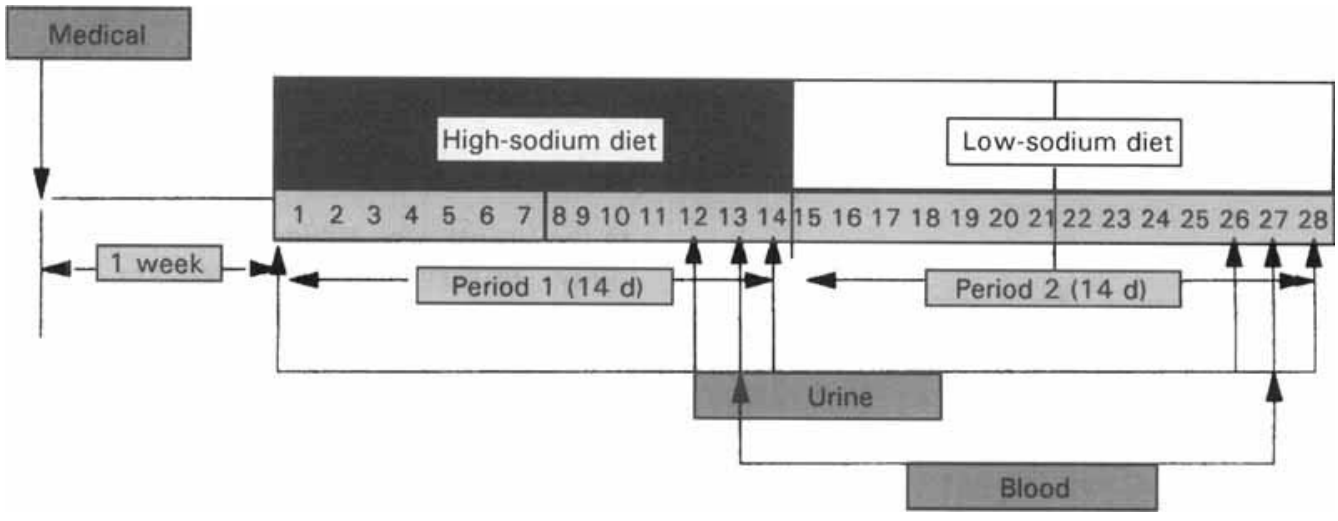

Fig. 1. Schedule of study design.

period. Portions of urine were stored at $-20^{\circ}$ from the morning of collection until required for analysis. Blood was collected by venepuncture into vacutainer tubes and was processed to serum which was immediately stored at $-70^{\circ}$ until required.

\section{Experimental techniques}

Urinary pyridinoline and deoxypyridinoline. Samples were analysed in duplicate using a three-step procedure. Urine was first hydrolysed with an equal volume of $12 \mathrm{M}-\mathrm{HCl}$ at $110^{\circ}$ for $18 \mathrm{~h}$, the crosslinks were then extracted by CF1 cellulose chromatography with the use of an internal standard (acetylated pyridinoline, MetraBiosystems Ltd, Wheatley, Oxon., UK) and were measured using a reversed-phase HPLC method with fluorescence detection (Colwell et al. 1993). The intra-assay CV for pyridinoline (Pyr) and Dpyr were $9 \%$ and $13 \%$ respectively. Interassay variation was avoided by analysing all samples from an individual in the same run.

Urinary creatinine. Fresh daily urine samples were analysed in duplicate by a colorimetric procedure using a diagnostic kit (catalogue no. 124 192; Boehringer Mannheim GmbH, Mannheim, Germany). The intra- and interassay $\mathrm{CV}$ were $3.2 \%$ and $6.7 \%$ respectively.
Urinary calcium, magnesium, sodium and potassium. $\mathrm{Ca}$ and $\mathrm{Mg}$ were analysed in duplicate in urine samples by atomic absorption spectrophotometry (Pye-Unicam Atomic Absorption Spectrophotometer, Model SP9, Cambridge, Cambs., UK) after appropriate dilution with $\mathrm{LaCl}_{3}$ solution ( $5 \mathrm{~g} / \mathrm{l}, \mathrm{BDH} \mathrm{Ltd}$, Poole, Dorset, UK). A range of $\mathrm{Ca}$ and $\mathrm{Mg}$ standards were used to obtain $\mathrm{Ca}$ and $\mathrm{Mg}$ calibration curves. The intra- and interassay $\mathrm{CV}$ for $\mathrm{Ca}$ were $2.8 \%$ and $7.8 \%$, and for $\mathrm{Mg}$ were $3.2 \%$ and $8.8 \%$ respectively. $\mathrm{Na}$ and $\mathrm{K}$ were determined in the urine samples by flame photometry (Model 435/455, Evans Electroselenium Ltd Halstead, Essex, UK) using appropriate $\mathrm{Na}$ and $\mathrm{K}$ standards. The intra- and interassay $\mathrm{CV}$ for $\mathrm{Na}$ were $3.8 \%$ and $6.9 \%$, and for $\mathrm{K}$ were $4.5 \%$ and $9.3 \%$ respectively.

Urinary cyclic AMP. Cyclic AMP was measured in first morning void urine samples using an ELISA (Amersham International, Amersham, Bucks., UK). The intra-assay CV was $7.6 \%$ and interassay variation was avoided by analysing all samples from an individual in the same run.

Serum osteocalcin and bone-specific alkaline phosphatase. Serum bone-specific alkaline phosphatase (EC 3.1.3.1) levels were measured in serum samples using a recently developed ELISA (MetraBiosystems Ltd). The intra-assay CV was $4.5 \%$. Serum osteocalcin levels were measured in serum samples using an ELISA (BRI- 

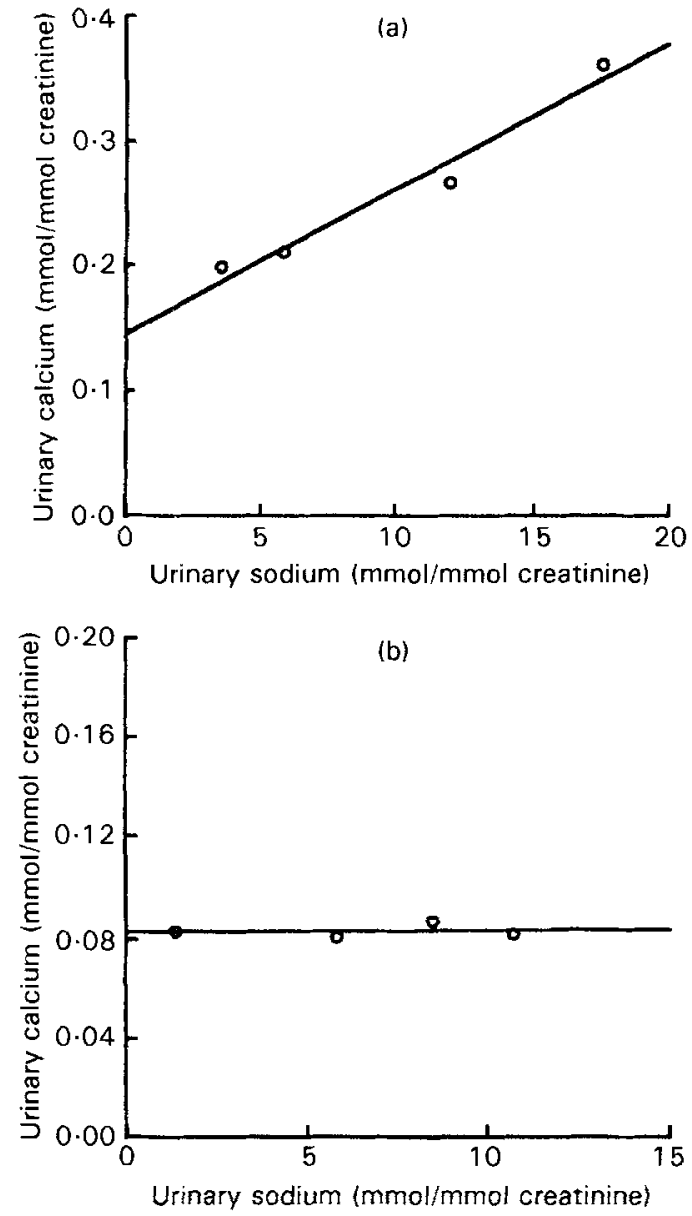

Fig. 2. Typical relationship between urinary calcium and urinary sodium, expressed relative to creatinine, in sodium-sensitive (a) and sodium-non-sensitive (b) individuals, on increasing dietary sodium intake from $40 \mathrm{mmol} / \mathrm{d}$ to $200 \mathrm{mmol} / \mathrm{d}$ and maintaining a constant $\mathrm{Ca}$ intake of $12.5 \mathrm{mmol} / \mathrm{d}$. Panel (a): $y=0.14+0.01 x, r 0.982$. Panel (b): $y=8.21 e^{-2}+1.27 e^{-4} x, r 0.176$.

Diagnostics, Dublin 9, Ireland). The intra-assay $\mathrm{CV}$ was $11 \%$. Interassay variation for both serum osteocalcin and bone-specific alkaline phosphatase was avoided by analysing all samples from an individual in the same run.

Serum calcium and magnesium. Both $\mathrm{Ca}$ and $\mathrm{Mg}$ were analysed in duplicate in serum samples according to previously described methods (Trudeau \& Freier, 1967; Pesce \& Kaplan, 1987). The intra-assay CV were $3.1 \%$ and
$2.8 \%$ respectively. There was no interassay variation as all samples from an individual were analysed in the same run.

\section{Statistical analysis}

Data are presented as means with their standard errors. The relationships between urinary $\mathrm{Ca} / \mathrm{Cr}$ and urinary $\mathrm{Na} / \mathrm{Cr}$ for the twenty-nine subjects were assessed by single linear regression analysis and Pearson's correlation coefficients.

Changes in the different biochemical indices during lowand high-Na periods in Na-sensitive and Na-non-sensitive groups were analysed by two-way ANOVA with the repeated measures design. Paired Student's $t$ tests were used to compare the low- and high-Na diets in each group with respect to the various biochemical indices. Unpaired Student's $t$ tests were used to compare the Na-sensitive and $\mathrm{Na}$-non-sensitive groups either at low or high $\mathrm{Na}$ intakes with respect to the various biochemical indices.

\section{Results}

In the twenty-nine subjects who took part in the screening study urinary $\mathrm{Ca}$ increased on average by 0.66 $\mathrm{mmol} / 100 \mathrm{mmol}$ increase in urinary $\mathrm{Na}$. Eight out of the twenty-nine subjects screened were deemed to be $\mathrm{Na}$ sensitive, i.e. their urinary excretion of $\mathrm{Ca} / \mathrm{Cr}$ increased significantly $(P<0.05)$ in response to increased $\mathrm{Na}$ intake. These eight subjects, together with eight subjects chosen randomly from the twenty-one subjects who were $\mathrm{Na}$ nonsensitive were selected for the intervention trial.

There was no significant difference between the Nasensitive and Na-non-sensitive groups for age, weight, height or BMI (Table 2).

Dietary $\mathrm{Ca}$ intakes were similar during the low- and high-Na periods for both the Na-sensitive and Na-nonsensitive groups (Table 3 ). Similarly, there were no significant differences in the dietary intakes of energy, protein, $\mathrm{P}$ or $\mathrm{K}$ between the low- and high-Na dietary periods in either group or between the groups at either intake (Table 3).

The effects of increasing $\mathrm{Na}$ intake from 80 to $180 \mathrm{mmol} / \mathrm{d}$ for $14 \mathrm{~d}$ on serum and urinary biochemical variables are shown in Table 4 . Urinary $\mathrm{Cr}$ concentration was similar for both Na-sensitive and non-sensitive groups and was unaffected by dietary Na intake. Urinary excretion of $\mathrm{Na} / \mathrm{Cr}$ increased significantly $(P<0.05)$ for both groups when $\mathrm{Na}$ intake was increased from 80 to $180 \mathrm{mmol} / \mathrm{d}$.

Table 2. Characteristics of the sodium-sensitive and sodium-non-sensitive groups of young women seiected for the intervention trial (Mean values with their standard errors)

\begin{tabular}{|c|c|c|c|c|c|}
\hline & \multicolumn{2}{|c|}{ Na-sensitive $(n 8)$} & \multicolumn{2}{|c|}{ Na-non-sensitive $(n 8)$} & \multirow[b]{2}{*}{$P$ value* } \\
\hline & Mean & SEM & Mean & SEM & \\
\hline Age (years) & 22.1 & 0.2 & 23.3 & 0.3 & 0.09 \\
\hline Height $(m)$ & 1.60 & 0.01 & 1.64 & 0.01 & 0.30 \\
\hline Weight (kg) & 59.5 & 0.9 & 56.5 & 1.3 & 0.30 \\
\hline BMI $\left(\mathrm{kg} / \mathrm{m}^{2}\right)$ & $21 \cdot 3$ & 0.3 & 21.1 & 0.9 & 0.80 \\
\hline
\end{tabular}

\footnotetext{
* Comparison of means between Na-sensitive and Na-non-sensitive groups using unpaired Student's $t$ test.
} 
Table 3. Mean daily nutrient intakes from the final $3 \mathrm{~d}$ during low- and high-sodium dietary periods for sodium-sensitive and sodium-non-sensitive groups of young women*

(Mean values with their standard errors)

\begin{tabular}{|c|c|c|c|c|c|c|c|c|}
\hline \multirow[b]{3}{*}{ Nutrient } & \multicolumn{4}{|c|}{ Na-sensitive ( $n$ 8) } & \multicolumn{4}{|c|}{ Na-non-sensitive (n 8) } \\
\hline & \multicolumn{2}{|c|}{ Low $\mathrm{Na}$} & \multicolumn{2}{|c|}{ High $\mathrm{Na}$} & \multicolumn{2}{|c|}{ Low $\mathrm{Na}$} & \multicolumn{2}{|c|}{ High $\mathrm{Na}$} \\
\hline & Mean & SEM & Mean & SEM & Mean & SEM & Mean & SEM \\
\hline Energy (kJ) & 7642 & 865 & 6933 & 422 & 6047 & 397 & 7396 & 602 \\
\hline Energy (kcal) & 1864 & 211 & 1691 & 103 & 1475 & 97 & 1804 & 147 \\
\hline Protein (g) & $48 \cdot 8$ & 4.9 & 55.0 & 4.8 & 53.7 & 4.4 & 61.7 & 4.9 \\
\hline Fibre (NSP) $+(\mathrm{g})$ & 10.8 & 1.2 & 8.9 & $1 \cdot 1$ & 9.8 & 0.7 & $12 \cdot 3$ & 2.4 \\
\hline $\mathrm{Ca}(\mathrm{mmol})$ & $12 \cdot 1$ & 1.2 & 11.9 & 1.8 & 13.5 & $2 \cdot 9$ & 13.7 & 3.6 \\
\hline$P(\mathrm{mmol})$ & 27.6 & $2 \cdot 3$ & 27.3 & 2.7 & 27.5 & 2.5 & 31.3 & 3.8 \\
\hline $\mathrm{K}$ (mg) & 2023 & 206 & 1904 & 203 & 2342 & 276 & 2755 & 299 \\
\hline
\end{tabular}

" Statistical analyses of nutrient intakes were made between each dietary period and between both groups using paired and unpaired Student's $t$ tests. No significant differences were found.

+ Total NSP measured according to Englyst \& Cummings (1988)

Table 4. Urinary and serum biochemical variables in sodium-sensitive and sodium-non-sensitive healthy young women during low and high sodium intakes

(Mean values with their standard errors)

\begin{tabular}{|c|c|c|c|c|c|c|c|c|}
\hline & \multicolumn{4}{|c|}{ Na-sensitive $(n 8)$} & \multicolumn{4}{|c|}{ Na-non-sensitive $(n 8)$} \\
\hline & \multicolumn{2}{|c|}{ Low $\mathrm{Na}$} & \multicolumn{2}{|c|}{ High $\mathrm{Na}$} & \multicolumn{2}{|c|}{ Low Na } & \multicolumn{2}{|c|}{ High $\mathrm{Na}$} \\
\hline & Mean & SEM & Mean & SEM & Mean & SEM & Mean & SEM \\
\hline \multicolumn{9}{|l|}{ Urine } \\
\hline Creatinine $(\mathrm{Cr})(\mathrm{mmol} / \mathrm{l})$ & $16 \cdot 4$ & 1.5 & 12.4 & 1.3 & 14.6 & $2 \cdot 1$ & 14.8 & 1.7 \\
\hline $\mathrm{Na}(\mathrm{mmol} / \mathrm{mmol} \mathrm{Cr})$ & 5.5 & 0.6 & $10 \cdot 5^{*}$ & 1.7 & $6 \cdot 1$ & 1.0 & $11 \cdot 0^{*}$ & 1.4 \\
\hline $\mathrm{Ca}(\mathrm{mmol} / \mathrm{mmol} \mathrm{Cr})$ & 0.15 & 0.02 & $0.26^{\star}$ & 0.04 & 0.15 & 0.02 & $0.14 \dagger \dagger$ & 0.03 \\
\hline $\mathrm{K}(\mathrm{mmol} / \mathrm{mmol} \mathrm{Cr})$ & $2 \cdot 7$ & 0.4 & $4 \cdot 1$ & 1.0 & 3.7 & 0.6 & 3.6 & 0.5 \\
\hline $\mathrm{Mg}(\mathrm{mmol} / \mathrm{mmol} \mathrm{Cr})$ & 0.31 & 0.03 & 0.33 & 0.02 & 0.32 & 0.06 & 0.31 & 0.02 \\
\hline Cyclic AMP ( $\mathrm{mmol} / \mathrm{mmol} \mathrm{Cr})$ & 0.15 & 0.03 & 0.24 & 0.05 & 0.23 & 0.03 & 0.23 & 0.05 \\
\hline $\mathrm{Pyr}(\mathrm{nmol} / \mathrm{mmol} \mathrm{Cr})$ & 33.4 & 1.7 & $36 \cdot 6$ & 2.5 & 35.6 & 1.7 & $35 \cdot 1$ & 1.9 \\
\hline Dpyr (nmol/mmol Cr) & $8 \cdot 3$ & 0.5 & 8.9 & 0.5 & $9 \cdot 1$ & 0.6 & $9 \cdot 2$ & 0.7 \\
\hline \multicolumn{9}{|l|}{ Serum } \\
\hline $\mathrm{Ca}(\mathrm{mmol} / \mathrm{l})$ & 2.37 & 0.09 & $2 \cdot 19$ & 0.08 & 2.21 & 0.06 & 2.27 & 0.08 \\
\hline $\mathrm{Mg}(\mathrm{mmol} / \mathrm{l})$ & 0.81 & 0.04 & 0.81 & 0.05 & 0.90 & 0.04 & 0.82 & 0.04 \\
\hline B-Alkphase (U/I) & 14.4 & 1.4 & 16.0 & 0.9 & $17 \cdot 6$ & 1.9 & 16.7 & 1.5 \\
\hline Osteocalcin $(\mu \mathrm{g} / \mathrm{l})$ & $16 \cdot 2$ & $2 \cdot 1$ & 16.4 & 1.6 & $16 \cdot 1$ & $2 \cdot 4$ & $12 \cdot 7$ & 1.7 \\
\hline
\end{tabular}

Pyr, pyridinoline; Dpyr, deoxypyridinoline; B-Alkphase, bone-specific alkaline phosphatase.

Mean values were significantly different from those for the low-Na treatment within a sensitivity group, ${ }^{*} P<0.05$.

Mean value was significantly different from that for the corresponding Na-sensitive group, $\dagger+P<0.0 t$.

There was no significant difference in urinary excretion of $\mathrm{Na} / \mathrm{Cr}$ between the $\mathrm{Na}$-sensitive and $\mathrm{Na}$-non-sensitive groups at either the low- or high-Na intakes.

Urinary excretion of $\mathrm{Ca} / \mathrm{Cr}$ increased significantly $(P<0.05)$ when $\mathrm{Na}$ intake was increased from 80 to $180 \mathrm{mmol} / \mathrm{d}$ in the Na-sensitive, but not the Na-nonsensitive group. While there was no significant difference in urinary $\mathrm{Ca} / \mathrm{Cr}$ levels between the Na-sensitive and nonsensitive groups on the low-Na diet, urinary excretion of $\mathrm{Ca} / \mathrm{Cr}$ was significantly higher $(P<0.05)$ in the Nasensitive group compared with the non-sensitive group when both were on the high-Na diet.

There were no significant differences in urinary $\mathrm{K} / \mathrm{Cr}$ or $\mathrm{Mg} / \mathrm{Cr}$ excretion or urinary cyclic AMP concentration between the high- and low-Na diets in either the Nasensitive or non-sensitive groups or between the Nasensitive and non-sensitive groups for either diet. Similarly, there were no significant differences in serum $\mathrm{Ca}$ or $\mathrm{Mg}$ concentrations between the low- and high-Na diets in either group or between the two groups for either diet.

There were no significant differences in urinary $\mathrm{Pyr} / \mathrm{Cr}$ or Dpyr/Cr excretion between the high- and low-Na diets in either the Na-sensitive or non-sensitive group or between the Na-sensitive and non-sensitive groups for either diet.

Similarly, in the case of the biochemical markers of bone formation, there were no significant differences in serum bone-specific alkaline phosphatase or serum osteocalcin levels between the high- and low-Na diets in either the Nasensitive or non-sensitive group or between the $\mathrm{Na}$ sensitive and non-sensitive group for either diet.

\section{Discussion}

It is well established that increasing dietary $\mathrm{Na}$ intake within the usual range of dietary intakes increases urinary $\mathrm{Ca}$ excretion and that there is a large variability in $\mathrm{Na}$ - 
induced calciuria between individuals. However, there is considerable uncertainty about whether $\mathrm{Na}$-induced urinary $\mathrm{Ca}$ losses result in increased bone resorption. If there is such an effect on bone it would appear to be more likely to be observed in those in whom urinary $\mathrm{Ca}$ is most affected by $\mathrm{Na}$. However, there are no studies to date on the influence of dietary $\mathrm{Na}$ on bone metabolism in $\mathrm{Na}$-sensitive and Na-non-sensitive subjects.

The average increase of urinary $\mathrm{Ca}$ in response to increased dietary $\mathrm{Na}$ in the twenty-nine subjects who took part in the screening study $(0.66 \mathrm{mmol} / 100 \mathrm{mmol}$ increase in urinary $\mathrm{Na}$ ) was similar to results obtained in other studies of similarly-aged premenopausal women which reported increases in urinary $\mathrm{Ca}$ of about $0.65 \mathrm{mmol}$ (Breslau et al. 1982), $0.70 \mathrm{mmol}$ (Shortt et al. 1988) and $0.60 \mathrm{mmol}$ (Itoh \& Suyama, 1996) per $100 \mathrm{mmol}$ increase in urinary $\mathrm{Na}$. There was a marked variation in the response between individuals, ranging from no significant response to $4.61 \mathrm{mmol} / 100 \mathrm{mmol}$ increase in urinary $\mathrm{Na}$ intake and a significant response was observed in eight out of the twenty-nine subjects.

This dependence of urinary $\mathrm{Ca}$ excretion on urinary $\mathrm{Na}$ excretion in the Na-sensitive subjects has been attributed to the existence of linked or common reabsorption pathways for both ions in the convoluted portion of the proximal tubule and thick ascending loop of Henle (Shortt \& Flynn, 1990). The reasons for the lack of, or at least much reduced, dependency of urinary $\mathrm{Ca}$ excretion on urinary $\mathrm{Na}$ excretion in the Na-non-sensitive subjects are unclear.

Urinary $\mathrm{Na}$ excretion was approximately twofold greater in subjects consuming the high- $\mathrm{Na}$ diet compared with those consuming the low-Na diet. This increase in urinary $\mathrm{Na}$ was associated with a $73 \%$ increase in urinary $\mathrm{Ca}$ for the $\mathrm{Na}$-sensitive group but urinary $\mathrm{Ca}$ was unchanged in the $\mathrm{Na}$-non-sensitive group. The increase in urinary $\mathrm{Ca}$ was not influenced by other dietary factors (e.g. Ca, protein, fibre, $\mathrm{P}$ or $\mathrm{K}$ ) which have been reported to influence urinary $\mathrm{Ca}$ excretion (Heaney \& Recker, 1982; Massey \& Wise, 1984) since the intakes of these were similar for the low-Na and high-Na diets.

Increasing $\mathrm{Na}$ intake had no effect on the excretion of Pyr or Dpyr in either the Na-sensitive or non-sensitive groups. This is in agreement with Evans et al. (1997) who recently reported that urinary Dpyr was unaffected by dietary $\mathrm{Na}$ in premenopausal women. Earlier studies in young subjects have reported that higher $\mathrm{Na}$ intakes are associated with increased urinary excretion of hydroxyproline (Goulding \& Lim, 1983; Goulding et al. 1986, Goulding \& MacDonald, 1986; Chan et al. 1992; Itoh \& Suyama, 1996) although Castenmiller et al. (1985) found no association of Na-induced calciuria with urinary hydroxyproline excretion. However, the suitability of urinary hydroxyproline as a marker of bone resorption has been questioned due to its lack of specificity and sensitivity and the changes in hydroxyproline excretion may not necessarily reflect changes in bone metabolism, but rather may be due to contributions from other sources, e.g. connective tissues, or from an alteration in the liver catabolism of hydroxyproline (Leitz et al. 1997). Additionally, in a number of these studies, dietary hydroxyproline was not controlled and it has been well established that dietary hydroxyproline may affect urinary hydroxyproline excretion (Kivirikko, 1970; Massey \& Whiting, 1996).

$\mathrm{Na}$ loading also had no significant effect on serum osteocalcin or serum bone-specific alkaline phosphatase, markers of bone formation (Delmas, 1992). This suggests that not only was the resorptive process unaffected by increased $\mathrm{Na}$ intake but also that bone formation and thus, bone turnover, were unaffected by varying the $\mathrm{Na}$ load.

Increased urinary $\mathrm{Ca}$ loss may temporarily depress plasma $\mathrm{Ca}$, leading to enhanced parathyroid hormone (PTH) secretion which helps to restore plasma $\mathrm{Ca}$ by increasing bone resorption and, via increased 1,25 dihydroxycholecalciferol, increasing intestinal absorption of $\mathrm{Ca}$ (Shortt \& Flynn, 1990).

There is evidence that serum PTH is increased in association with $\mathrm{Na}$-induced calciuria (McCarron et al. 1981; Breslau et al. 1982), although this was not observed in the study of Evans et al. (1997). PTH was not measured in the present study but urinary cyclic AMP, a specific marker of PTH action on the kidney, did not change in response to increasing dietary $\mathrm{Na}$ intake. It may be that the increase in PTH only occurs over the first few days of $\mathrm{Na}$ stress and that PTH levels would have returned to normal values by the twelfth day of the study when blood samples were taken.

Increasing $\mathrm{Na}$ intake has been reported to lead to a significant increase in fractional $\mathrm{Ca}$ absorption in healthy young adults by an average of 8-25\% (Meyer et al. 1976; Breslau et al. 1982), although Evans et al. (1997) did not observe any effect of increasing dietary $\mathrm{Na}$ on $\mathrm{Sr}$ absorption (an index of $\mathrm{Ca}$ absorption) in premenopausal women. However, the authors of the latter study suggested that the precision of this method may have been too low to detect a change.

The lack of effect of $\mathrm{Na}$ on urinary pyridinium crosslinks in the young women in the present study and in the premenopausal women studied by Evans et al. (1997) suggests that the $\mathrm{Na}$-induced urinary $\mathrm{Ca}$ loss is compensated for by increased $\mathrm{Ca}$ absorption rather than increased bone resorption. Thus, the adaptive processes in these subjects appear to be adequate to protect bone, even with the restricted $\mathrm{Ca}$ intake $(12.5 \mathrm{mmol} / \mathrm{d})$ used in the present study.

However, the capacity for such adaptation may be limited in some individuals, e.g. those with impaired parathyroid function or postmenopausal women with impaired renal function, poor vitamin D status or poor intestinal Ca absorption (Shortt \& Flynn, 1990). Impaired adaptation may explain the increased urinary excretion of pyridinium crosslinks in postmenopausal women when $\mathrm{Na}$ intake was increased from 50 to $300 \mathrm{mmol} / \mathrm{d}$ (Evans et al. 1997), although it should be noted that Lietz et al. (1997) did not observe this in a similar study using a lower Na load $(60-170 \mathrm{mmol} / \mathrm{d})$. Impaired adaptation was also suggested in the study of Breslau et al. (1985) who found no increase in intestinal $\mathrm{Ca}$ absorption in seven osteoporotic postmenopausal women when $\mathrm{Na}$ intake was increased from 10 to $250 \mathrm{mmol} / \mathrm{d}$ while dietary $\mathrm{Ca}$ was maintained at $10 \mathrm{mmol} / \mathrm{d}$. Evans et al. (1997) suggested that maladaptation to high $\mathrm{Na}$ intake may contribute to the development of postmenopausal osteoporosis. 
In conclusion, the present study shows that increasing $\mathrm{Na}$ intake from 80 to $180 \mathrm{mmol} / \mathrm{d}$ significantly increases urinary $\mathrm{Ca}$ excretion in some individuals ( $\mathrm{Na}$-sensitive) but not others (Na-non-sensitive). However, it appears that in these healthy young women this Na-induced calciuria does not result in increased bone resorption or turnover and that adaptation of dietary $\mathrm{Ca}$ absorption may compensate for the increased urinary $\mathrm{Ca}$ loss.

\section{Acknowledgement}

This research has been part-funded by grant aid under the Food Sub-Programme of the Operational Programme for Industrial Development which is administered by the Department of Agriculture, Food and Forestry, Dublin, and supported by national and European Union funds.

\section{References}

Aub JC, Tibbetts DM \& McLean R (1937) The influence of parathyroid hormone, urea, sodium chloride, fat and of intestinal activity upon calcium balance. Journal of Nutrition 13, 635-655.

Breslau NA, McGuire JL, Zerwekh JE \& Pak CYC (1982) The role of dietary sodium on renal excretion and intestinal absorption of calcium and on vitamin D metabolism. Journal of Clinical Endocrinology and Metabolism 55, 369-373.

Breslau NA, Sakhaee K \& Pak CYC (1985) Impaired adaptation to salt-induced urinary calcium losses in postmenopausal osteoporosis. Transactions of the Association of American Physicians 98, 107-115.

Castenmiller JJM, Mensink RP, Van der Heijden L, Kouwenhoven T, Hautvast JGAJ, de Leeuw PW \& Schaafsma G (1985) The effect of dietary sodium on urinary calcium and potassium excretion in normotensive men with different calcium intakes. American Journal of Clinical Nutrition 41, 52-60.

Chan ELP, Ho CS, MacDonald D, Chan TYK \& Swaminathan R (1992) Interrelationships between urinary sodium, calcium, hydroxyproline and serum PTH in healthy subjects. Acta Endocrinology 127, 242-245.

Colwell R, Russell RGG \& Eastell R (1993) Factors affecting the assay of urinary 3-hydroxypyridinium cross-links of collagen as markers of bone resorption. European Journal of Clinical Investigation 23, 341-349.

Delmas PD (1992) Clinical use of biochemical markers of bone remodelling in osteoporosis. Bone 13, S17-S21.

Devine A, Criddle RA, Dick IM, Kerr DA \& Prince RL (1995) A longitudinal study of the effect of sodium and calcium intakes on regional bone density in postmenopausal women. American Journal of Clinical Nutrition 62, 740-745.

Englyst HN \& Cummings JH (1988) Improved method for measurement of dietary fiber as non-starch polysaccharides in plant foods. Journal of the Association of Official Analytical Chemists 71, 808-814.

Evans CEL, Chughati AY, Blumsohn A, Giles M \& Eastell R (1997) The effect of dietary sodium on calcium metabolism in premenopausal and postmenopausal women. European Journal of Clinical Nutrition 51, 394-399.

Goulding A (1981) Fasting urinary sodium/creatinine in relation to calcium/creatinine and hydroxyproline/creatinine in a general population of women. New Zealand Medical Joumal 93, 294 297.

Goulding A, Everitt HE, Cooney JM \& Spears GFS (1986) Sodium and osteoporosis. In Recent Advances in Clinical Nutrition, vol. 2, pp. 99-108 [ML Wahlquist and AS Truswell, editors]. London: John Libbey.
Goulding A \& Lim PE (1983) Effects of varying dietary salt intake on the fasting urinary excretion of sodium, calcium and hydroxyproline in young women. New Zealand Medical Journal 96, 853-854.

Goulding A \& McDonald B (1986) Intra-individual variability in fasting urinary calcium/creatinine and hydroxyproline/creatinine measurements. In Recent Advances in Clinical Nutrition, vol. 2, pp. 312-313 [ML Wahlqvist and AS Truswell, editors]. London: John Libbey.

Greendale GA, Barrett-Connor E, Edelstein S, Ingles S \& Haile R (1994) Dietary sodium and bone mineral density: results of a 16-year follow-up study. Journal of the American Geriatric Society 42, 1050-1055.

Heaney RP \& Recker RR (1982) Effects of nitrogen, phosphorus and caffeine on calcium balance in women. Journal of Laboratory and Clinical Medicine 99, 46-55.

Hills A, Parsons D, Webster G, Rosenthal O \& Conover H (1959) Influence of the renal excretion of sodium chloride upon the renal excretion of magnesium and other ions by human subjects. Journal of Clinical Endocrinology and Metabolism 19, 1192-1211.

Itoh R \& Suyama Y (1996) Sodium excretion in relation to calcium and hydroxyproline excretion in a healthy Japanese population. American Journal of Clinical Nutrition 63, 735-740.

King JS, Jackson R \& Ashe B (1964) Relation of sodium intake to urinary calcium excretion. Investigative Urology 1, 555-560.

Kivirikko K (1970) Urinary excretion of hydroxyproline in health and disease. International Review of Connective Tissue Research 5, 93-163.

Kleeman CR, Bohannan J, Bernstein D, Ling S, \& Maxwell MH (1964) Effect of variations in sodium intake on calcium excretion in normal humans. Proceedings of the Society for Experimental Biology and Medicine 115, 29-32.

Leitz G, Avenell A \& Robins SP (1997) Short-term effects of dietary sodium intake on bone metabolism in postmenopausal women measured using urinary deoxypyridinoline excretion. British Journal of Nutrition 78, 73-82.

McCarron DA, Rankin LI, Bennet WM, Krutzik S, McClung MR \& Luft FC (1981) Urinary calcium excretion at extremes of sodium intake in normal man. American Journal of Nephrology 1, 84-90.

McParland BE, Goulding A \& Campbell AJ (1989) Dietary salt affects biochemical markers of resorption and formation of bone in elderly women. British Medical Joumal 299, 834-835.

Massey LK \& Whiting SJ (1996) Dietary salt, urinary calcium and bone loss. Journal of Bone and Mineral Research 11, 731-736.

Massey LK \& Wise KJ (1984) The effect of dietary caffeine on urinary excretion of calcium, magnesium, sodium and potassium in healthy young females. Nutrition Research 4, 43-50.

Matkovic V, Ilich JZ, Andon MB, Hseieh LC, Tzagournis Lagger BJ \& Goel PK (1995) Urinary calcium, sodium and bone mass of young females. American Journal of Clinical Nutrition $\mathbf{6 2}$ $417-425$.

Meyer WJ, Transbol I, Bartter FC \& Delea C (1976) Control of calcium absorption: effect of sodium chloride loading and depletion. Metabolism 25, 989-993.

Need AG, Morris HA, Cleghorn DB, De Nichilo D, Horowitz M \& Nordin BEC (1991) Effect of salt restriction on urine hydroxyproline excretion in postmenopausal women. Archives of Internal Medicine 151, 757-759.

Nordin BEC, Need AG, Morris HA \& Horowitz M (1993) The nature and significance of the relationship between urinary sodium and urinary calcium in women. Joumal of Nutrition $123,1615-1622$

Nordin BEC \& Polley KJ (1987) Metabolic consequences of the menopause: a cross-sectional, longitudinal and intervention study on 557 normal postmenopausal women. Calcified Tissue International 41, S1-S59. 
Paul AA \& Southgate DAT (1978) McCance and Widdowson's The Composition of Foods, 4th ed. London: H.M. Stationery Office.

Pesce A \& Kaplan LA (1987) Methods in Clinical Chemistry, p. 1021. St Louis, MO: C. V. Mosby Co.

Shortt C \& Flynn A (1990) Sodium-calcium inter-relationships with specific reference to osteoporosis. Nutrition Research Reviews 3, 101-115.
Shortt C, Flynn A \& Morrissey PA (1988) Influence of dietary sodium intake on urinary calcium excretion in selected Irish individuals. European Journal of Clinical Nutrition 42, 595603.

Trudeau DL \& Freier EF (1967) Determination of calcium in urine and serum by atomic absorption spectrophotometry (AAS). Clinical Chemistry 13, C101-Cl14. 